\title{
DISTRIBUTION OF ABO AND RH-D BLOOD GROUPS IN THE CACHAR DISTRICT OF BARAK VALLEY OF ASSAM: IMPLICATION FOR REGIONAL BLOOD TRANSFUSION SERVICE
}

\author{
Dharmakanta Kumbhakar ${ }^{1}$
}

${ }^{1}$ Associate Professor, Department of Pathology, Tezpur Medical College and Hospital, Tezpur, Assam.

\section{ABSTRACT}

\section{BACKGROUND}

$\mathrm{ABO}$ and Rhesus (Rh)-D blood group antigens are integrated parts of the red blood cell membranes. They are hereditary characters and are useful in population genetic studies, in resolving medico-legal issues and more importantly in compatibility test in blood transfusion and organ transplant practices. They show a wide geographical and racial variation. The knowledge of the distribution of $\mathrm{ABO}$ and $\mathrm{Rh}-\mathrm{D}$ blood groups among different population is essential in health care and transfusion practices.

\section{AIMS AND OBJECTIVES}

To study the distribution of ABO and Rh-D blood groups amongst the population of Cachar district of Barak valley of Assam.

\section{MATERIALS AND METHODS}

We did a retrospective analysis of records of 1,60,500 blood samples grouped for ABO and Rh-D typing at Silchar Medical College and Hospital Blood Bank, Silchar, over a period of 10 years from 1 ${ }^{\text {st }}$ January 1999 to $31^{\text {st }}$ December 2008.

\section{RESULTS AND OBSERVATIONS}

Out of total 1,60,500 blood samples grouped for $\mathrm{ABO}$ and Rh-D typing during the period in the centre, the distribution of phenotype A, B, AB and 0 were $24.80 \%(39,804), 32.00 \%(51,360), 5.60 \%(8,986)$ and $37.60 \%(60,350)$ respectively. The Rh-D positive phenotype was $95.40 \%(1,53,117)$ and remaining $4.60 \%(7,383)$ was Rh-D negative. The frequency of Rh-D phenotypes in the various ABO blood groups was as - A Positive 23.70\% (38,039), A Negative 1.10\% (1,765), B Positive 30.80\% (49,433), B Negative $1.20 \%$ (1,927), AB Positive 5.40\% (8,665), AB Negative 0.20\% (321), O Positive 35.50\% (56,980) and 0 Negative $2.10 \%$ $(3,370)$ respectively.

\section{DISCUSSION}

Silchar Medical College and Hospital Blood Bank receives blood samples for grouping of almost all population of Cachar district. Hence, the data revealed in the present study fairly reflects the prevalence of ABO and Rh-D groups distribution in the Cachar district in Barak valley of Assam.

\section{CONCLUSION}

The present study provide information on the status of $\mathrm{ABO}$ and Rh-D blood groups distribution of the region and the knowledge of it will help in effective management of regional blood transfusion service of the area.

\section{KEYWORDS}

Blood Group, ABO and Rhesus-D, Hereditary, Phenotype, Blood Transfusion, Health Care.

HOW TO CITE THIS ARTICLE: Kumbhakar D. Distribution of ABO and Rh-D blood groups in the Cachar district of Barak Valley of Assam: Implication for regional blood transfusion service. J. Evolution Med. Dent. Sci. 2016;5(58):4017-4021, DOI: $10.14260 /$ jemds/2016/919

\section{INTRODUCTION}

Blood group antigens are integrated parts of the red blood cell membranes.[1,2] Despite the long list of several other blood groups discovered so far, the $\mathrm{ABO}$ and Rh-D blood groups hold a respectable position in view of safety of blood/blood products transfusion, more importantly in compatibility test in blood transfusion and organ transplant to date.[3,4] The knowledge of the distribution of $\mathrm{ABO}$ and $\mathrm{Rh}$ D blood groups is essential for effective management of blood bank inventory, being it a smaller local transfusion service or a regional or national transfusion service.

Financial or Other, Competing Interest: None.

Submission 13-06-2016, Peer Review 07-07-2016,

Acceptance 13-07-2016, Published 20-07-2016.

Corresponding Author:

Dr. Dharmakanta Kumbhakar,

Married Doctor's Flat C-3,

Gauhati Medical College and Hospital Campus,

P.O. Indrapur, Ghy-32, Kamrup (Metro), Assam

E-mail:drkdharmakanta@yahoo.com

DOI: $10.14260 /$ jemds/2016/919
$\mathrm{ABO}$ and $\mathrm{Rh}-\mathrm{D}$ blood group antigens are genetically determined. ${ }^{[5,6]}$ They are the most frequently studied genetic markers in a large group of population. ${ }^{[7]} \mathrm{ABO}$ and $\mathrm{Rh}$ gene and phenotypes vary widely across geographical boundaries despite the fact that the antigens involved are stable throughout the life. ${ }^{[8]} \mathrm{A}$ racial difference in the distribution of these blood groups has been noted by some researchers. Apart from their importance in blood transfusion practice, the $\mathrm{ABO}$ and $\mathrm{Rh}-\mathrm{D}$ blood group antigens are useful in population genetic studies, researching population migration patterns, evaluating the probability of haemolytic disease in the new born as well as resolving certain medico-legal issues, particularly disputes in paternity/maternity and for forensic purposes. ${ }^{[9]}$ It is, therefore, imperative to have information on the distribution of these blood groups in any population.[10]

No study has been done investigating the ABO blood group and Rh-D typing frequency in any population in and around Cachar district of Barak valley of Assam till date. Hence, data on frequency of $\mathrm{ABO}$ and Rh-D phenotypes in the population of this area are not available. 
The population structure of Cachar district with over 10 lacks people, mainly comprises of Bengali, Assamese, Manipuri and Bodos. The Silchar Medical College and Hospital Blood Bank, Silchar, occupies an important place in the health sector of Cachar district of Barak valley of Assam. This blood bank receives blood samples for grouping from almost all population of Cachar district being blood donors, blood recipients, patients admitted and attended for treatment, routine antenatal care as well as for routine medical examinations of Silchar Medical College Hospital and other government and private health establishments. Thus the Silchar Medical College and Hospital Blood Bank does and keeps records of blood groups of these all. Hence, we did a retrospective analysis of records of $\mathrm{ABO}$ grouping and Rh-D typing of the blood donors, transfusion recipients and patients attending antenatal care or some other medical interventions at Silchar Medical College and Hospital Blood Bank, Silchar, over a period of 10 years from 1st January 1999 to $31^{\text {st }}$ December 2008. This study seeks to provide data on $\mathrm{ABO}$ and Rh-D groups distribution in the Cachar district in Barak valley of Assam. The collation of immuno-haematology data would therefore enhance sustainable regional blood bank services in the region of Cachar district.

\section{MATERIALS AND METHODS}

Records of ABO and Rh-D blood groupings of blood donors, transfusion recipients and patients attending routine antenatal care as well as individuals who presented for routine medical examination at Silchar Medical College and Hospital Blood Bank, Silchar between $1^{\text {st }}$ January 1999 and 31 $1^{\text {st }}$ December 2008 (10 years) were examined and a care was exercised to eliminate any repeated entry. All entries were double checked by the author.

$\mathrm{ABO}$ and Rh-D blood groupings were carried out in our blood bank between $1^{\text {st }}$ January 1999 and 30th June 2003 by standard tiles technique with appropriate positive and negative controls using one drop of whole blood mixed with one drop of appropriate anti-sera and rocked gently and read for agglutination under microscope after 30 minutes. In case of doubt, the results were confirmed by reverse grouping using known Group A and B red blood cells. ${ }^{[2,11]}$

From $1^{\text {st }}$ July 2003 to $31^{\text {st }}$ December $2008, \mathrm{ABO}$ and Rh-D blood groupings were carried out in our blood bank by tube sedimentation method. Both cell and serum grouping were carried out for the entire samples with appropriate positive and negative controls. For cell grouping (Table 1), one drop of $5 \%$ three times washed cell suspension was mixed with one drop of appropriate anti-sera, mixed well and read for agglutination after 30 minutes keeping the tubes at 37 degrees centigrade in incubator.[2,11] In case of doubt, the test was examined under microscope. Results were confirmed by reverse (Serum) grouping (Table 2) using known Group A and $B$ red blood cells.[2,11] Data on the frequency of ABO and Rh-D blood groups were reported in simple numbers and percentage.

\begin{tabular}{|c|c|c|c|c|c|c|}
\hline Anti-A & Anti-B & Anti-AB & Saline & ABO Group & Anti-D & Rh-D Group \\
\hline Agglutination & No Agglutination & Agglutination & No Agglutination & $\mathrm{A}$ & Agglutination & Rh-D Positive \\
\hline No Agglutination & Agglutination & Agglutination & No Agglutination & B & $\begin{array}{c}\text { No } \\
\text { Agglutination }\end{array}$ & Rh-D Negative \\
\hline Agglutination & Agglutination & Agglutination & No Agglutination & $\mathrm{AB}$ & & \\
\hline No Agglutination & No Agglutination & No Agglutination & No Agglutination & 0 & & \\
\hline
\end{tabular}

\begin{tabular}{|c|c|c|c|}
\hline A Pooled Cell & B Pooled Cell & O Pooled Cell & ABO Group \\
\hline No Agglutination & Agglutination/Haemolysis & No Agglutination & A \\
\hline Agglutination/Haemolysis & No Agglutination & No Agglutination & B \\
\hline No Agglutination & No Agglutination & No Agglutination & AB \\
\hline Agglutination/Haemolysis & Agglutination/Haemolysis & No Agglutination & 0 \\
\hline \multicolumn{2}{|r}{} \\
\hline
\end{tabular}

\section{RESULTS AND OBSERVATIONS}

During the period of 10 years between $1^{\text {st }}$ January 1999 and $31^{\text {st }}$ January 2008, a total of $1,60,500$ blood samples were collected in Silchar Medical College and Hospital Blood Bank for $\mathrm{ABO}$ and $\mathrm{Rh}-\mathrm{D}$ grouping.

\begin{tabular}{|c|c|c|}
\hline Sources of Blood Samples & Numbers & Percentage \\
\hline Blood Donor & 71,525 & $44.56 \%$ \\
\hline Transfusion Recipient & 50,110 & $31.22 \%$ \\
\hline Antenatal case & 31,025 & $19.33 \%$ \\
\hline Routine Medical case & 7,840 & $4.89 \%$ \\
\hline Total & $\mathbf{1 , 6 0 , 5 0 0}$ & $\mathbf{1 0 0 . 0 0 \%}$ \\
\hline Table 3: Different Sources of Samples for ABO \\
and Rh-D Grouping \\
\hline
\end{tabular}

Table 3 shows that out of total 1,60,500 samples 71,525 $(44.56 \%)$ were from blood donors; 50,110 (31.22\%) were from transfusion recipients; 31,025 (19.33\%) were from antenatal cases and 7,840 (4.89\%) were from routine medical samplings. Figure 1 shows the numbers and Figure 2 shows the percentage of different sources of samples for ABO and Rh-D grouping.

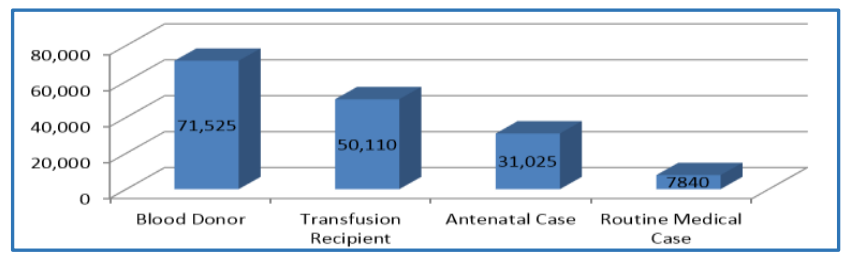

Fig. 1: Diagram showing Different Sources of Samples for $A B O$ and Rh-D Grouping (Numbers) 


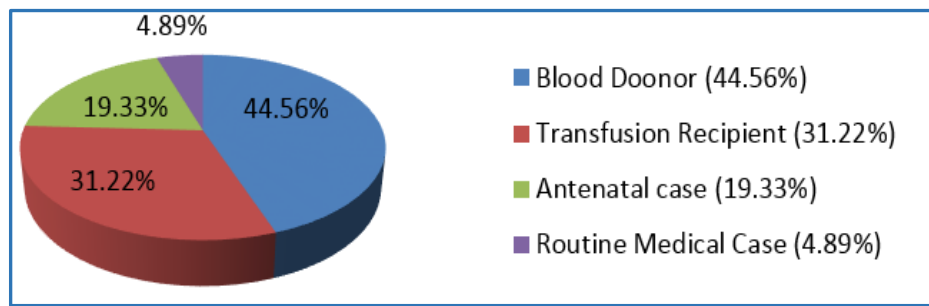

Fig. 2: Diagram showing Different Sources of Samples for $A B O$ and $R h-D$ Grouping (Percentage)

\begin{tabular}{|c|c|c|c|c|c|c|}
\hline \multirow{2}{*}{ Blood Samples } & \multicolumn{3}{|c|}{ ABO Blood Group Phenotypes } & \multicolumn{2}{c|}{ Rh-D Phenotype } \\
\cline { 2 - 7 } & Group-A & Group-B & Group-AB & Group-0 & Rh-D Positive & Rh-D Negative \\
\hline Number & 39,804 & 51,360 & 8,986 & 60,350 & $1,53,117$ & 7383 \\
\hline Percentage & $24.80 \%$ & $32.00 \%$ & $5.60 \%$ & $37.60 \%$ & $95.40 \%$ & $4.60 \%$ \\
\hline
\end{tabular}

Table 4 shows the distribution of various ABO and Rh-D phenotypes among the sample studied. The frequency of Group 0 phenotype was the most prevalent at $37.60 \%$ $(60,350)$ followed by B at $32.00 \%(51,360), A$ at $24.80 \%$ $(39,804)$ and $A B$ at $5.60 \%(8,986)$. Rh-D antigen was detected in $1,53,117 \quad(95.40 \%)$ samples, while $\mathrm{Rh}-\mathrm{D}$ negative phenotype was found in $7,383(4.60 \%)$ samples in the total sample size of $1,60,500$. Figure 3 shows the numbers of different $\mathrm{ABO}$ and $\mathrm{Rh}-\mathrm{D}$ phenotypes among the sample studied. Figure 4 shows the percentage of different ABO Group and Figure 5 shows percentage of Rh-D phenotypes in the study sample.

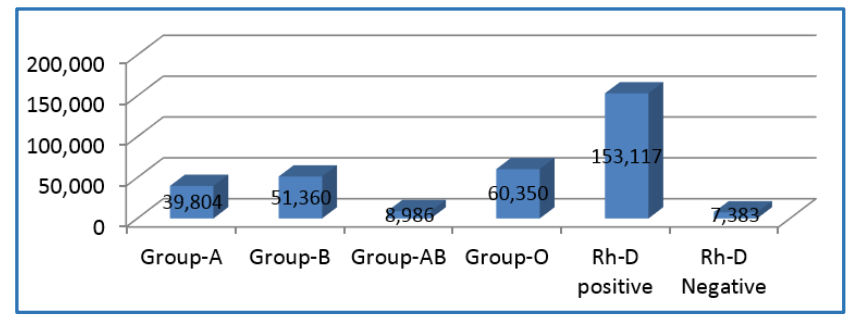

Fig. 3: Diagram showing Numbers of Different ABO Blood Group and in Rh-D Phenotypes the Study Group

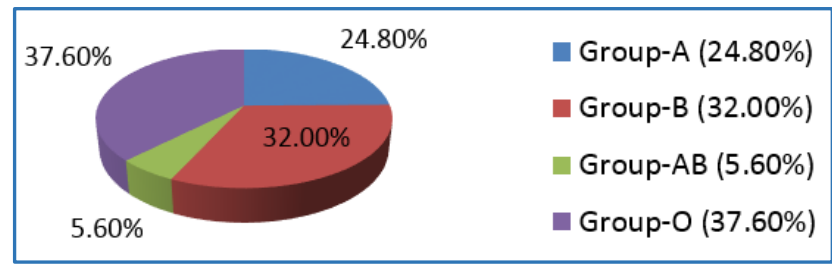

Fig. 4: Diagram showing Percentage of Different ABO Blood Group in the Study Group

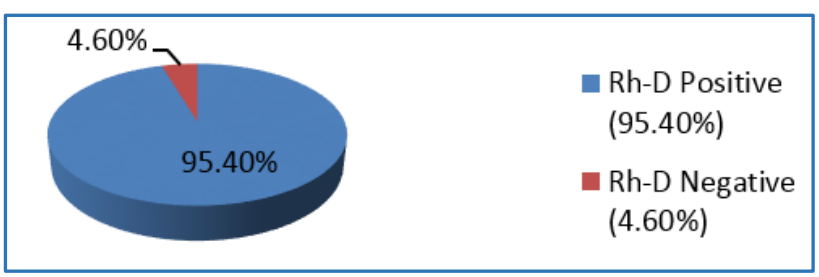

Fig. 5: Diagram showing Percentage of Different Rh-D Grouping

\begin{tabular}{|c|c|c|c|c|c|c|c|c|c|}
\hline Blood Samples & A Pos. & A Neg. & B Pos. & B Neg. & AB Pos. & AB Neg. & O Pos. & O Neg. & Total \\
\hline Numbers & 38,039 & 1,765 & 49,433 & 1,927 & 8,665 & 321 & 56,980 & 3,370 & $1,60,500$ \\
\hline Percentage & $23.70 \%$ & $1.10 \%$ & $30.80 \%$ & $1.20 \%$ & $5.40 \%$ & $0.20 \%$ & $35.50 \%$ & $2.10 \%$ & $100 \%$ \\
\hline
\end{tabular}

Table 5 shows the frequency of Rh-D Phenotypes among the samples studied with respect to $A B O$ blood groups. Rh-D positivity to blood Group O, A, B, AB were found in the study as 56,980 (35.50\%), 38,039 (23.70\%), 49,433 (30.80\%) and $8,665(5.40 \%)$ respectively. Rh-D negativity to blood Group 0,

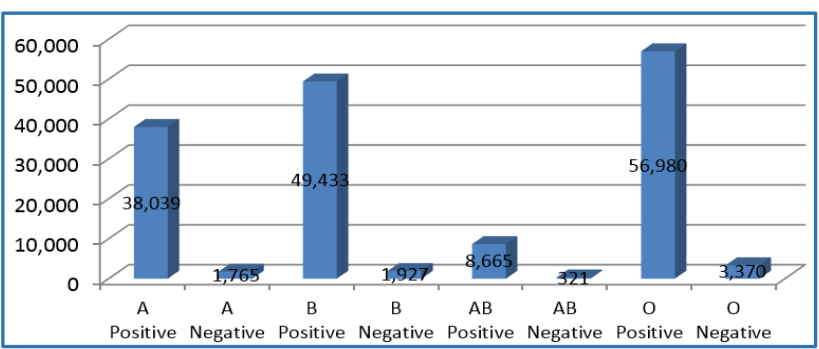

Fig. 6: Diagram showing Numbers of Samples showing Rh$D$ Typing amongst Different $A B O$ Groups
$\mathrm{A}, \mathrm{B}, \mathrm{AB}$ were found in the study as $3,370(2.10 \%), 1,765$ (1.10\%), 1,927 (1.20\%) and $321(0.20 \%)$ respectively. Figure 6 shows the numbers and Figure 7 shows the percentage of samples showing Rh-D typing amongst different $A B O$ groups.

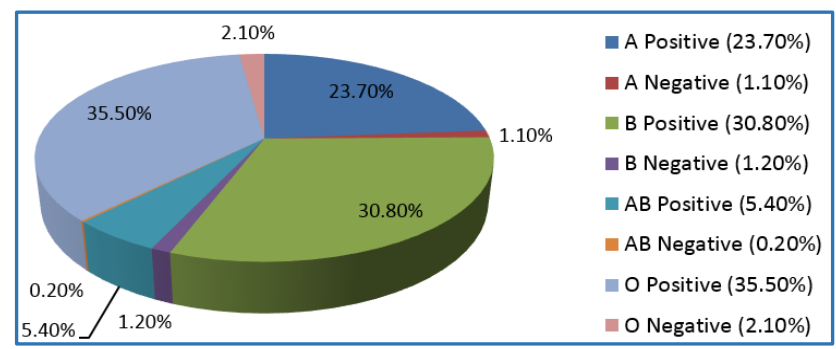

Fig. 7: Diagram showing Percentage of Samples showing Rh-D Typing amongst Different ABO Groups 


\begin{tabular}{|c|c|c|c|c|c|c|c|c|c|c|c|c|}
\hline $\begin{array}{c}\text { Blood } \\
\text { Samples }\end{array}$ & $\begin{array}{c}\text { A } \\
\text { Pos. }\end{array}$ & $\begin{array}{c}\text { A } \\
\text { Neg. }\end{array}$ & $\begin{array}{c}\text { A } \\
\text { Total }\end{array}$ & $\begin{array}{c}\text { B } \\
\text { Pos. }\end{array}$ & $\begin{array}{c}\text { B } \\
\text { Neg. }\end{array}$ & $\begin{array}{c}\text { B } \\
\text { Total }\end{array}$ & $\begin{array}{l}\text { AB } \\
\text { Pos. }\end{array}$ & $\begin{array}{c}\text { AB } \\
\text { Neg. }\end{array}$ & $\begin{array}{c}\text { AB } \\
\text { Total }\end{array}$ & $\begin{array}{c}0 \\
\text { Pos. }\end{array}$ & $\begin{array}{c}0 \\
\text { Neg. }\end{array}$ & $\begin{array}{c}0 \\
\text { Total }\end{array}$ \\
\hline Numbers & 38,039 & 1,765 & 39,804 & 49,433 & 1,927 & 51,360 & 8,665 & 321 & 8,986 & 56,980 & 3,370 & 60,350 \\
\hline Percentage & $95.57 \%$ & $4.43 \%$ & $100 \%$ & $96.25 \%$ & $3.75 \%$ & $100 \%$ & $96.43 \%$ & $3.57 \%$ & $100 \%$ & $94.42 \%$ & $5.58 \%$ & $100 \%$ \\
\hline \multicolumn{13}{|c|}{ Table 6: The Frequency of Rh-D amongst $A, B, A B$ and $O$ Groups } \\
\hline
\end{tabular}

Table 6 shows the frequency of Rh-D phenotypes among the samples studied with respect to individual blood groups. The Rh-D positivity and negativity to total $60,350(100 \%)$ Group 0 samples showed 56,980 (94.42\%) and 3,370 (5.58\%), whereas total 8,986 (100\%) AB Group was 8,665 (96.43\%) and 321 (3.57\%); total 39,804 (100\%) A Group was 38,039 (95.57\%) and 1,765 (4.43\%); total 51,360 (100\%) B Group was 49,433 (96.25\%) and 1,927 (3.75\%).

\section{DISCUSSION}

$\mathrm{ABO}$ and $\mathrm{Rh}$ gene phenotypes vary widely across races and geographical boundaries despite the facts that the antigens involved are stable throughout the life.[12] The resultant polymorphism remains important in population genetic studies, estimating the availability of compatible blood, evaluating the probability of haemolytic disease of newborn, resolving disputes in paternity/maternity and forensic purposes. A racial difference in the distribution of blood groups has been noted by some researchers. ${ }^{[7,8]}$ Few studies on the prevalence of $\mathrm{ABO}$ and $\mathrm{Rh}$ blood groups have been carried out in the Indian population, and majority of these studies are limited to individual communities or to a particular region of the country.[13] No such study has yet been reported from Cachar district of Barak valley of Assam.

The present study revealed that blood Group 0 was the most prevalent at $37.60 \%$ followed by B at $32.0 \%$, A at $24.80 \%$ and $\mathrm{AB}$ at $5.60 \%$. This observation is in accordance with previous studies from other parts of India. The findings of studies conducted in the National Institute of Mental Health and Neuroscience, Bengaluru and on the population of some parts of Andhra Pradesh reveal similar trends. Amongst Indians, Group 0 is highest.[14] However, the study in the North Indian population by Nanu A Thapliyal, Chandra and Gupta and Agarwal et al reported blood Group B to be the most prevalent.[13] Similar results with predominance of blood Group B have also been noted in a study conducted in Gujarat. Some other studies from different parts of Europe, America and South-East Asia have reported blood Group 0 to be the commonest blood group (Table 7). Group 0 has been found to be more amongst Indian tribes of America, a section of Australian and Africa, North-Eastern Europeans, etc. White people of America, West Europeans and West Asians have a higher frequency of Group A; whereas Group B is more common in Central and South-East Asians.

\begin{tabular}{|c|c|c|c|c|c|c|c|}
\hline \multirow{2}{*}{ ABO Phenotype } & \multicolumn{7}{|c|}{ Population } \\
\cline { 2 - 8 } & Caucasoid & Whites & Blacks & Mexicans & Asians & British & Indians \\
\hline Group-O & $47 \%$ & $45 \%$ & $49 \%$ & $56 \%$ & $43 \%$ & $46.7 \%$ & $37.5 \%$ \\
\hline Group-A & $41 \%$ & $41 \%$ & $28 \%$ & $28 \%$ & $27 \%$ & $41.7 \%$ & $24.7 \%$ \\
\hline Group-B & $09 \%$ & $10 \%$ & $19 \%$ & $13 \%$ & $25 \%$ & $8.6 \%$ & $32.5 \%$ \\
\hline Group-AB & $03 \%$ & $04 \%$ & $04 \%$ & $03 \%$ & $05 \%$ & $3.0 \%$ & $5.3 \%$ \\
\hline \multicolumn{7}{|c|}{ Table 7: ABO Phenotypes Frequencies amongst Different World Population } \\
\hline
\end{tabular}

The Rh-D blood group is the most polymorphic and its clinical significance in transfusion medicine is only next to the ABO blood group system.[5] The present study showed that the prevalence of Rhesus ' $\mathrm{D}$ ' antigen is $95.40 \%$. So Rh-D negative phenotype is $4.60 \%$. This finding is in agreement with the results of other studies in India. Rh-D negative phenotype is $5.0 \%$ in India, whereas it is $15 \%$ in Europe. There was no association between Rh-D status.

Mordant et al[6] have earlier shown that the frequency of $\mathrm{ABO} / \mathrm{Rh}-\mathrm{D}$ blood groups is valid only for the specific region or the specific population group from where the data were derived. The Silchar Medical College and Hospital Blood Bank receives blood samples for grouping of almost all population of Cachar district. Hence, the data revealed in the present study fairly reflects the prevalence of $\mathrm{ABO}$ and $\mathrm{Rh}-\mathrm{D}$ groups distribution in the Cachar district in Barak valley of Assam. The present study is therefore useful in providing information on the status of $\mathrm{ABO}$ and $\mathrm{Rh}-\mathrm{D}$ blood groups distribution in the region and the knowledge of it will help in effective management of regional blood transfusion service of the area.

\section{CONCLUSION}

With a large sample, we established that among the various $\mathrm{ABO}$ and Rh-D blood groups in the Cachar districts in Barak valley of Assam, Group $O$ is the commonest with Rh-D antigen, the occurrence of blood Group A and B with Rh-D antigen is nearly equal and frequency of $\mathrm{AB}$ is least. The frequency of Rh-D negative is, although, slightly lower in present series than the data of the country. The present study is therefore useful in providing information on the status of $\mathrm{ABO}$ and Rh-D blood groups distribution of the region and the knowledge of it will help in effective management of regional blood transfusion service of the area. However, studies of other minor blood group antigens are also needed in order to effective management for repeated transfusion dependant transfusions.

\section{REFERENCES}

1. Fischbach F. Nurses' quick reference to laboratory and diagnostic tests. $3^{\text {rd }}$ ed. Philadelphia, PA: Lippincott 2002:19-25.

2. Lewis SM, Bain JB, Imelda B. Dacie and Lewis practical haematology. 9th ed. Livingstone: Churchill 2001:483503.

3. Harmening DM. Modern blood banking and transfusion practices. $4^{\text {th }}$ ed. FA Davis Company, Philadelphia 1995:95-104 
4. Worllrdg S, Odiemudia SE, Thomas CO, et al. Blood group antigens and antibodies in Nigeria. A Trop Med Parasitol 1974;68(3):249-64.

5. Avent ND, Reid ME. The RH blood group system. Blood 2000;95(2):375-87.

6. Mordant AE, Koppes AC, Donmainiewski-Sobezek K. The distribution of blood groups and other polymorphism. $2^{\text {nd }}$ ed. Oxford University Press, London 1976.

7. Ahmed SG, Obi SO. The incidence of ABO and Rhesus-D blood group in Northern Nigeria. Nigeria J Med 1998;7:68-70.

8. Bakare AA, Azeez MA, Agbolade JO. Gene frequencies of $\mathrm{ABO}$ and rhesus blood groups and haemoglobin variants in Ogbomosho, South West Nigeria. Afr J Biotechnol 2012;13(2):147-53.

9. Guyton AC. Text book of physiology. $7^{\text {th }}$ ed. Livingstone: Churchill 1985:72-3.
10. Falusi AG, Ademowo OG, Latunji CA, et al. Distribution of ABO and RH genes in Nigeria. Afr J Med Sci 2000;29(1): 23-6.

11. Vengelen-Tyler. Technical manual. $12^{\text {th }}$ ed. USA: American Association of Blood Banks 2005.

12. Nathalang 0 , Kuvanont $S$, Punyaprasiddhi $P$, et al. A preliminary study of the distribution of blood group systems in Thai blood donors determined by the gel test. Southeast Asian J Trop Med Public Health 2001;32(1): 204-7.

13. Nanu A, Thapliyal RM. Blood group gene frequency in a selected North Indian population. Indian J Med Res 1997;106:242-6.

14. Reddy KS, Sudha G. ABO and RH blood groups among the Desuri Reddis of Chittur district, Andhra Pradesh. Anthropol 2009;11:237-8. 